\title{
Biology of Length-Weight Relationship and Condition Factor of Some Cichlids in Eleyele Lake, Oyo State, Nigeria
}

\author{
Adeosun Olubunmi", Bankole Adebukola Folake, Otuogbai Irene Omokhafe \\ Department of Fisheries Technology, Oyo State College of Agriculture, Igboora, Nigeria
}

"Corresponding author: Adeosun Olubunmi, Department of Fisheries Technology, Oyo State College of Agriculture, Igboora, Nigeria. Tel: +2347033832479; Email: moriyike2006@yahoo.com

Citation: Olubunmi A, Folake BA, Omokhafe OI (2017) Biology of Length- Weight Relationship and Condition Factor of Some Cichlids in Eleyele Lake, Oyo State, Nigeria. J Fish Aqua Dev: JFAD-122.

Received Date: 29 August, 2017; Accepted Date: 01 September, 2017; Published Date: 09 September, 2017

\begin{abstract}
The study was carried out to evaluate length-weight relationship and condition factor of five species of cichlids found in Eleyele Lake. Five species that were found throughout the study period are Tilapia zilli, Tilapia guineensis, Hemichromis fasciatus, Oreochromis niloticus and Sarotherodon melanotheron. The relationship between the length and weight of the fish species showed that they are allometric in growth and this implies that the fish species did not increase in weight faster than the cube of their lengths. The mean condition factor for the five species is 2.8 for Tilapia zilli, 2.3 for Sarotherodon melanotheron, 2.7 for Tilapia guineensis, 2.2 for Oreochromis niloticus and 2.1 for Hemichromis fasciatus. The study revealed that Hemichromis fasciatus and Oreochromis niloticus and Tilapia zilli dominated the lake during the study period.
\end{abstract}

Keywords: Cichlids; Condition factor; Length-Weight Relationship

\section{Introduction}

Growth fluctuations are more frequent in fishes of tropical subtropical water bodies due to several factors such as environmental variations, multiple spawning, dynamics of food compositions, physiological changes etc. Growth of fish is a mathematical function of length and weight and varies due to biological changes and seasonal dynamics [1]. The study of length weight relationship in fishes is of primary importance in setting up equations in estimating the number of fish landed as well as in comparison of population in time and space. The length-weight relationship of fish is an important fishery management tool. Its importance is pronounced in estimating the average weight at a given length group and in assessing the relative well being of a fish population [2]. Condition factor compares the well being of a fish and is based on the hypothesis that heavier fish of a given length are better-condition [3]. Condition factor has been used as an index of growth and feeding intensity.

Oyo State is completely land-locked and has no access to the sea. However, it is endowed with natural large water surface area and its domestic fish production is derived mainly from rivers, lakes and reservoirs (Dams) etc. Prominent among such wa- ter bodies are those lakes built by the water corporation of Oyo State and are located in various parts of the state (Table 1). Others include 14 lakes built by OYSADEP (Oyo State Agric. Development Programme): 1 by IITA: 1 by Railway Corporation: 3 by Ogun-Osun River Basin Development Authority (OORBDA) and 1 Natural lake at Ibusogbooro in Oyo West Local Government Area (Odo-Ogun). These lakes totaled 28 and covered a total water surface area of 10,175.19 hectares with 1,152 fisher folks, 962 canoes as at 1999 and 2,433.02 tonnes of fish were landed as at 2000 [4]. Therefore, the objectives of the study are to evaluate length-weight relationship and condition factor of five fish species in Eleyele Reservoir and investigate the species that is abundant during the study period.

\section{Materials and Methods}

\section{The Study Area}

The study was conducted at Eleyele reservoir, Ibadan Oyo State. Nigeria. The temperature of the area ranges from $25^{\circ} \mathrm{C}-30^{\circ} \mathrm{C}$ and the Longitude $7^{\circ} 23^{\prime} 49^{\prime \prime} \mathrm{N}$, Latitude $3^{\circ} 52^{\prime} 2^{\prime}$ 'E. Eleiyele reservoir was constructed by the Water Corporation of the old Western Region in 1939 primarily to supply water to Ibadan city by darning of the river Ona which itself covers a distance of 62Iun from its source to the dam. It has a surface area of 152.76ha and a storage capacity of 1550 million gallons; a maximum depth of $12 \mathrm{~m}$, and a 


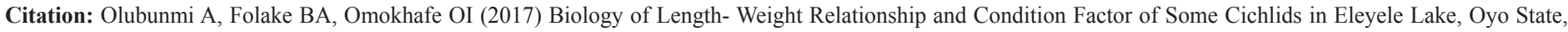
Nigeria. J Fish Aqua Dev: JFAD-122.

mean depth of $6.5 \mathrm{~m}$. Its basing is long and narrow and divided into two main stretches, with the narrowest part slightly over $20 \mathrm{~m}$ and the widest slightly above $250 \mathrm{~m}$. The dam receives water during the rainy season principally from the River Ona and other associated small streams, in addition to water from run-offs. The control of the fisheries of Eleiyele reservoir resides in the Oyo State Ministry of Agriculture and Natural resources acting through its Department of Fisheries. The Department of Fisheries exercises its powers under the relevant laws to formulate by-laws and regulations for the development, exploitation, management and protection of the fishery resources [4].

\section{Experimental design}

Fish specimens were procured from artisanal fishers and middlemen at the landing site. Sampling of landed catches was done once a month for a period of six months. The fishers used a range of fishing gear such as gill net, cast net set nets and traps. From the catches the fish specimens that were abundant were selected and kept in insulated containers for onward transportation to the department laboratory for further analysis.

\section{Length-Weight relationship and Condition Factor of fish}

The total length of the fish was measured from the tip of the mouth to the caudal fin using meter rule calibrated in centimeters. Fish were measured to the nearest centimeter. Fish weight was taken using a sensitive scale to the nearest gram. The mean length and weight of the different species were used for data analysis.

The relationship between the length (L) and weight (W) of fish was expressed by equation (Pauly, 1983) [5].

$$
\begin{gathered}
\mathrm{W}=\mathrm{aL}^{\mathrm{b}} \\
\text { Where } \\
\mathrm{W}=\text { weight of fish in }(\mathrm{g}) \\
\mathrm{L}=\text { total length }(\mathrm{TL}) \text { in }(\mathrm{cm}) \\
\mathrm{a}=\text { constant }(\text { Intercept }) \\
\mathrm{b}=\text { the length exponent (Slope) }
\end{gathered}
$$

The ' $a$ ' and ' $b$ ' values were obtained from a linear regression of the length and weight of fish. The correlation ' $r$ ' that is the degree of association between the length and weight was computed from the linear regression analysis.

$$
\mathrm{R}=\mathrm{r}^{2}
$$

The condition factor $(\mathrm{K})$ of the fish specimen was estimated from the relationship

$$
\mathrm{K}=\underline{100 \mathrm{~W}}
$$

$$
\begin{gathered}
\text { Where } \\
\mathrm{K}=\text { condition factor } \\
\mathrm{W}=\text { weight of fish }(\mathrm{g}) \\
\mathrm{L}=\text { length of fish }(\mathrm{cm})
\end{gathered}
$$

\section{Analysis of Data}

Regression analysis was performed to determine the relationship between length and weight of fish.

\section{Results and Discussion}

\section{Fish Species in Eleyele Reservoir}

Fish species that were found throughout the study period are Tilapia zilli, Sarotherodon melanotheron, Tilapia guineensis, Oreochromis niloticus and Hemichromis fasciatus Other fish species that were captured once or twice during the study period are Hespetus odoe, Hemichromis elongates, Clarias gariepinus, Heterotis niloticus and Tilapia galileaus. Akinyemi et al. (1986) [6] observed that fishing was done in Eleyele reservoir only during the dry season months of November to April and from visual observation and identifications of fish landing made by cooperative fishermen, they found out that the Cichlidae were most abundant and were dominated by Oreochromis niloticus, TIlapia zilli and Hemichromis fasciatus. The results obtained from this study also corroborate with the findings of Akinyemi et al. (1986) [6]. They also found out that in most cases, species of Hemichromis bimaculatus and Hemichromis fasciatus were observed to be thrown back into the reservoir by the fishermen whenever they were encountered in the catch but now all their catches were sold to the fish mongers.

\section{Length-Weight relationship}

The Length-weight relationship of the five fish species most abundant during the study period is presented in table1. The relationship between the length and weight of the fish species showed that they are allometric in growth and this implies that the fish species did not increase in weight faster than the cube of their lengths. Fish are said to exhibit isomeric growth when length increases in equal proportions with body weight for constant specific gravity. The regression co-efficient for isometric growth is ' 3 ' values greater or lesser than ' 3 ' indicate allometric growth (Gayando and Pauly, 1997) [7]. Several authors have reported both isometric and allometric growth for different fish species from various water bodies. King reported allometric growth for Tilapia species from Umuoseriche Lake. Abowei et al. (2009) [2] reported isometric growth for Ethmalosa Fimbriata, Illishia Africana and allometric growth for Sardinella. maderensis and Cynoglossus sengalensis from Nkoro river, Niger state. 


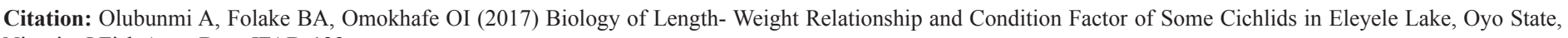
Nigeria. J Fish Aqua Dev: JFAD-122.

\begin{tabular}{|c|c|c|c|}
\hline Fish Species & Exponential equation & $\mathbf{R}^{\mathbf{2}}$ & $\mathbf{K}$ \\
\hline Tillapia zilli & $\mathrm{W}=777.6 \mathrm{e}^{-0.27 \mathrm{TL}}$ & 0.870 & 2.8 \\
\hline $\begin{array}{c}\text { Sarotherodon melan- } \\
\text { otheron }\end{array}$ & $\mathrm{W}=89.63 \mathrm{e}^{0.309 \mathrm{TL}}$ & 0.437 & 2.3 \\
\hline Tilapia guineensis & $\mathrm{W}=424.7 \mathrm{e}^{0.015 \mathrm{TL}}$ & 0.025 & 2.7 \\
\hline Oreochromis niloticus & $\mathrm{W}=195.3 \mathrm{e}^{0.015 \mathrm{TL}}$ & 0.079 & 2.2 \\
\hline Hemichromis fasciatus & $\mathrm{W}=154.2 \mathrm{e}^{0.108 \mathrm{TL}}$ & 0.880 & 2.1 \\
\hline
\end{tabular}

Table 1: Length-Weight relationship for the five species of Cichlids found in Eleyele reservoir

\section{Condition factor}

The graphical representation of the condition factor of each species studied is shown in figs. 1,3,5,7 and 9. The condition factor ranged from 2.2 to 3.9 for Tilapia zilli, 1.7-3.0 for Sarotherodon melanotheron, 1.8-5.3 for Tilapia guineensis, 1.8-2.5 for Oreochromis niloticus and 1.5-2.8 for Hemichromis fasciatus. There was difference in the condition factors for the combined fish and the monthly factor for each fish species studied. The condition factors obtained in this study is very close with the results obtained from other studies. Hatikakoty and Biswas (2004) [8] reported mean condition factor between 1.48 and 2.89 for Oreochromis mossambicus in different seasons.

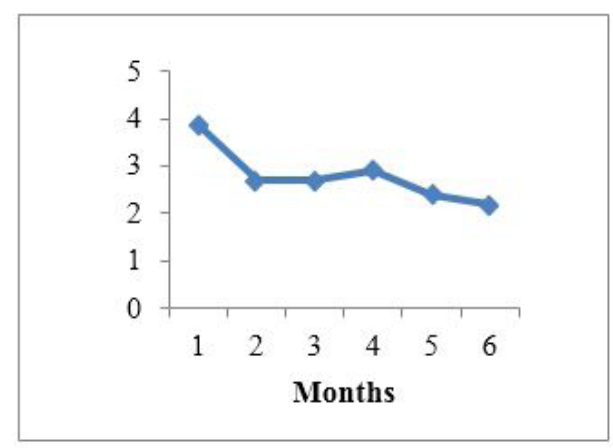

Figure 1: Condition factor of Tilapia zilli

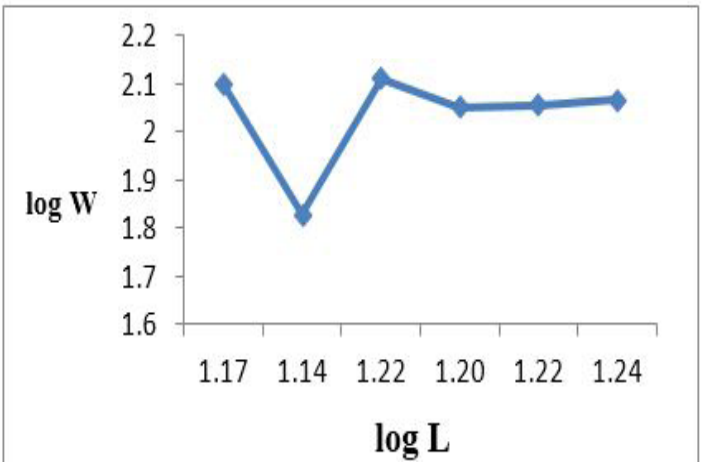

Figure 2: Length-Weight relationship of Tilapia zilli.

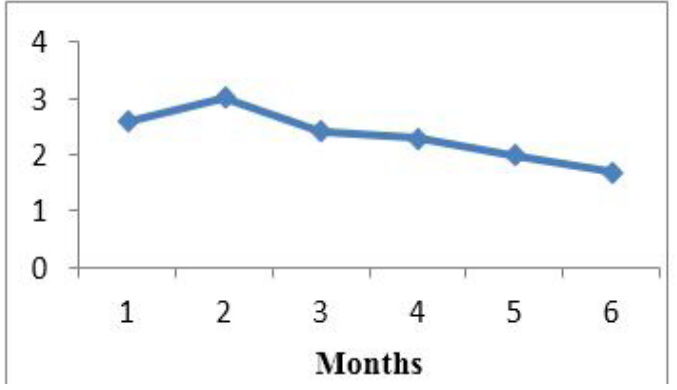

Figure 3: Condition factor for Sarotherodon melanotheron.

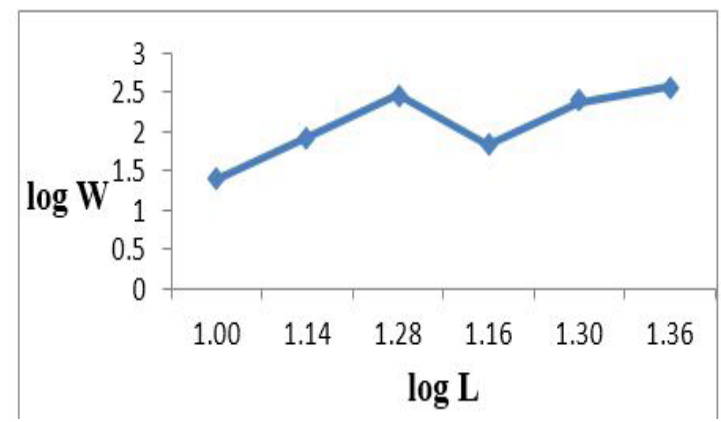

Figure 4: Length-Weight relationship for Sarotherodon melanotheron.

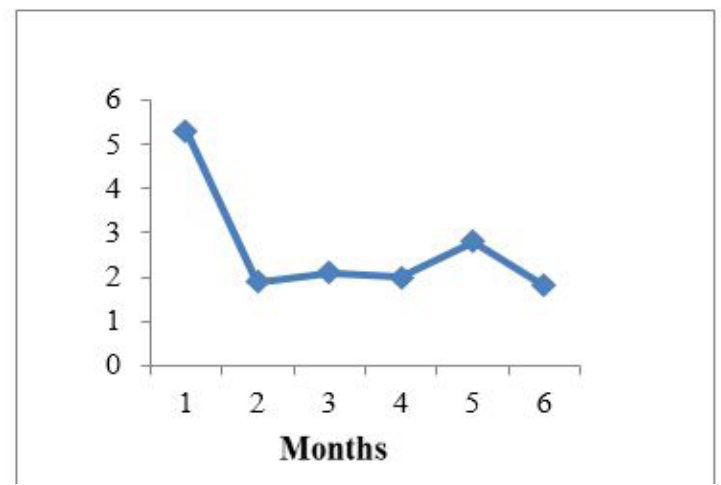

Figure 5: Condition factor for Tilapia guineensis.

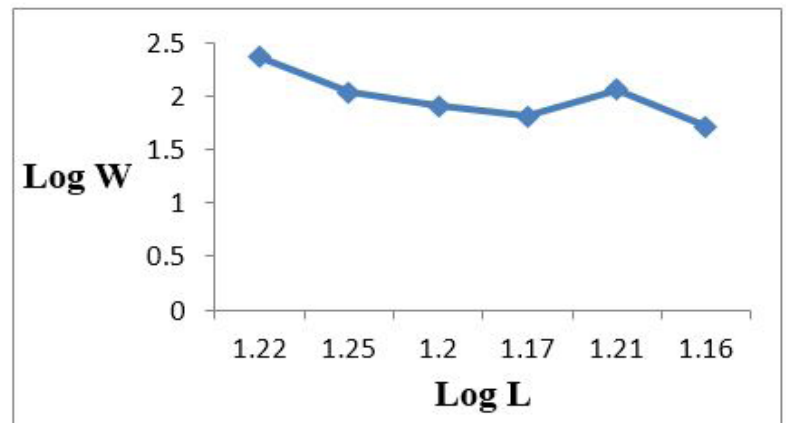

Figure 6: Length-weight relationship of Tilapia guineensis. 
Citation: Olubunmi A, Folake BA, Omokhafe OI (2017) Biology of Length- Weight Relationship and Condition Factor of Some Cichlids in Eleyele Lake, Oyo State, Nigeria. J Fish Aqua Dev: JFAD-122.

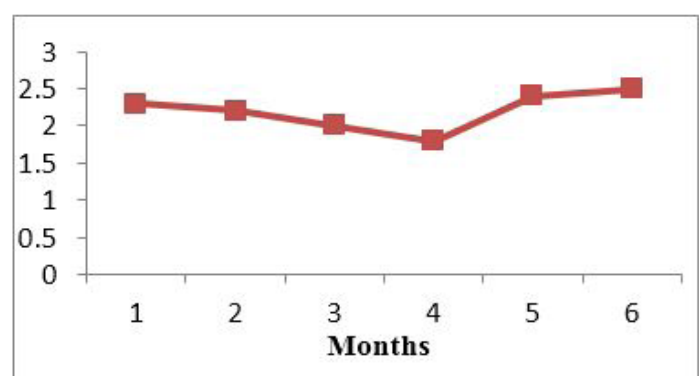

Figure 7: Condition factor for Oreochromis niloticus.

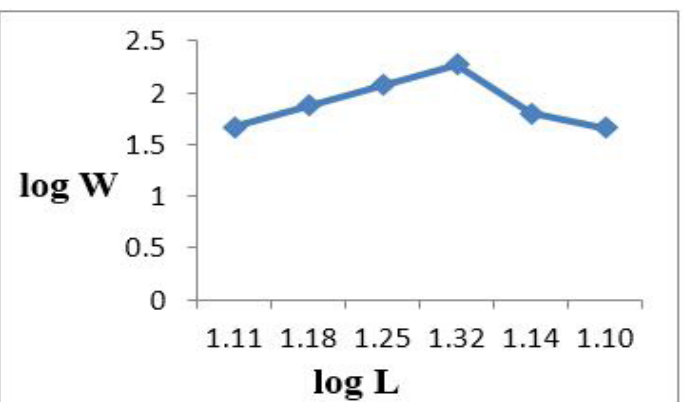

Figure 8: L-W Relationship of Oreochromis niloticus.

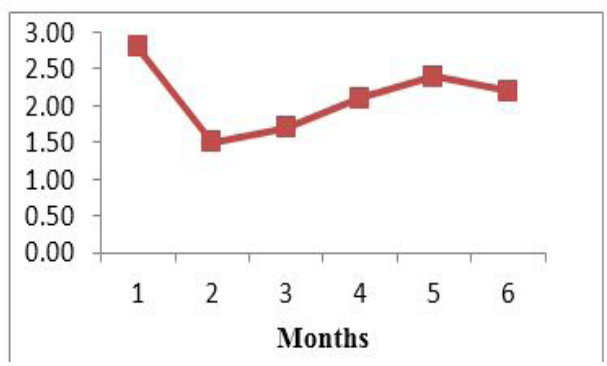

Figure 9: Condition Factor for Hemichromis fasciatus.

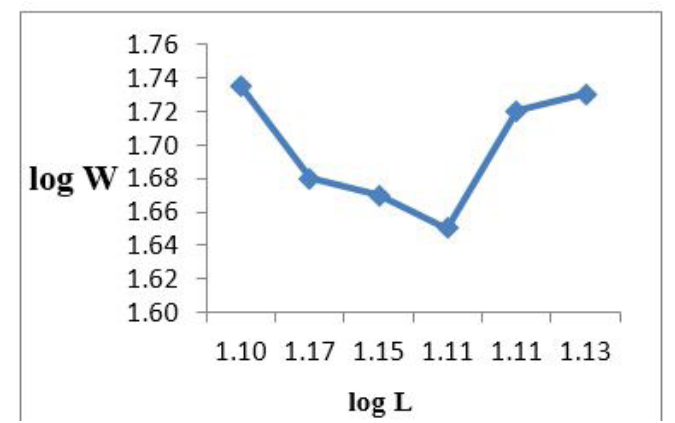

Figure 10: L-W relationship of Hemichromis fasciatus.

\section{Conclusion}

The value of condition factors obtained in this study showed that all the species studied were in good condition. Gayando and Pauly (1997) [7] reported that certain factors often affect the well being of a fish. The factors include data pulling, sorting into classes, sex, stages of maturity and state of the stomach [9].

\section{References}

1. Das SK (2004) Biology of length-weight and Condition in a Brackish water fish Liza tade (Forskal) In: Fishery Management by Professor Arvind Kumar A.P.H Publishing Corporation 5, Ansari Road, Darya Ganj New Delhi: 251-253.

2. Abowei JFN, Davies OA, Eli AA (2009) Study of the Length-weight relationship and condition factor of five fish species from Nkoro River, Niger Delta, Nigeria. Current Research Journal of Biological Sciences 1: $94-98$.

3. Bagenal TB, Tesch AT (1978) Conditions and Growth Patterns in Fresh Water Habitats. Blackwell Scientific Publications Oxford: 75-89.

4. Olubowale Ojo (2002) Lake Fisheries Management in Oyo State Preseason training for officers handling the IFAD-Assisted Artisanal Fisheries Development Project- Cage fish culture Trials-Second Cycle in Oyo State Held at The Fisheries Research Laboratory complex, Premier Hotel Road, Agodi Ibadan 1st March 2002.

5. Pauly D (1983) Some simple methods for the assessment of tropical fish stock. FAO Fish Tech Paper No 234: 52.

6. Akinyemi O, Ita EO, Sado EK (1986) A preliminary assessment of the post-impoundment fisheries of Lake Eleiyele and Lake Asejire, Oyo State, Nigeria. Kainji Lake Research Institute 1985 Annual Report: 4450.

7. Gayando FC, Pauly D (1997) FAO ICLARM stock assessment tools (FISAT): References Manual, FAO Computerized Information Series (Fisheries) 8: 262.

8. Hatikakoty G, Biswas SP (2004) Length-Weight relationship and condition factor of Oreochromis mossambicus (Peters) from a domestic pond, Nazira, Upper Assam in: Fishery Management by Professor Arvind Kumar A.P.H Publishing corporation 5, Ansari road, Darya Ganji, New Delhi-110002.

9. Le Cren ED (1951) The length-weight relationship and seasonal cycle in gonad weight and condition in the perch Perca fluviatilis. Journal of Animal Ecology 20: 201-219. 